\title{
DIAGNOSTICS OF THE MAIN GAS PIPELINES AND ASSESSMENT OF THEIR RESIDUAL LIFE UNDER THE CONDITIONS OF LONG- TERM OPERATION
}

\author{
Josyp Luchko'; Evgen Ivanyk ${ }^{2}$
}

\author{
${ }^{1}$ Lviv Branch of Dnipropetrovsk National University of Railway Transport \\ named after academician V. Lazaryan, Lviv, Ukraine \\ ${ }^{2}$ Hetman Petro Sahaidachnyi National Ground Forces Academy, Lviv, Ukraine
}

\begin{abstract}
Summary. The current state of the main gas pipelines diagnostics is analyzed in this paper. It is noted that the gas extraction and gas transportation complex now plays an important role in the structure of the Ukrainian economy and is considered to be an industry which should ensure the implementation of important projects aimed to reduce the energy crisis in the country. Some aspects of implementation of the main gas pipelines open and hidden areas diagnostics are considered. The methodological principles of the construction of the scientifically grounded method of formulation of the predictive estimation of the gas pipelines residual life under the conditions of long-term operation are described. The peculiarities of the implementation of such approach is that the basic calculations of the criteria are carried out within the framework of theories reflecting the main mechanisms of the bearing capacity exhaustion of the gas pipelines pipe material, in particular, according to the criterion of static strength, taking into account the corrosion and deterioration of the material, estimation of the residual life according to the criterion of low cycle fatigue allowing to predict the residual life of the pipeline, taking into account the processes of the origin of fatigue cracks near constructive stress concentrators, estimating the residual resources according to the criterion of crack resistance. On the basis of the data obtained during the diagnosis, and the results of calculations the recommendations for the repair, replacement and strengthening of dangerous parts of main gas pipelines are developed; their regular diagnostics makes it possible to determine effectively the technical condition and allows to establish the expediency of further operation and recommendations for the elimination of detected defects.
\end{abstract}

Key words: main pipelines diagnostics, gas complexes, algorithm, modern methods of the material corrosion and fatigue resistance, low-cycle fatigue, detection.

Introduction. At present gas production and gas pipeline complex play an important role in the structure of Ukraine economy and is considered to be the branch which should provide the important projects implementation aimed to decrease the energy crisis in Ukraine. The act „About pipeline transport“ states that the main pipeline transport is of prime national economy and defense importance and is state-owned.

A great number of main gas pipelines (MGP) with long-term operation are used currently. Hence in $19975500 \mathrm{~km}$ of the MGP with more than 30 years operation time were used. That is why it is very important to have reasonable methods and solutions providing the main pipelines reliable operation; that is scientifically proved diagnostic system should contribute to saving of costs on equipment operation as well as its safety and reliability during operation. Diagnostics is the entire branch able to respond appropriately to all the requirements 
of supporting MGP working ability. Additional financial expenses are needed for diagnostic means application but they are covered due to the accident prevention and increase of the MP operation reliability. At the same time the negative influence on the environment is reduced due to the reduction of gas release into the atmosphere.

Ukraine gas industry is the leading branch of fuel and energy complex. Besides the function of national economy energy supply, Ukraine gas pipeline system carries out gas delivery to European countries.

The total length of pipeline system is 34 thousand kilometers. The pipelines with large diameter dominate in the MGP structure. Thus the pipelines with diameter $1420 \mathrm{~mm}$ amount to $15,65 \%$, with diameter $1220-1020 \mathrm{~mm}-23,63 \%, 820-720 \mathrm{~mm}-14,85 \%$.

At the same time Ukraine gas-transportation system (GTS) includes $58 \%$ of pipelines with working service from 15 to 50 years, furthermore 5.8 thousand $\mathrm{km}$ of pipelines completed their service live in 33 years [1]. More than one third of the pipelines have corrosion-resistant coating from polymer films of frosting coating. From year to year Ukraine GTS is deteriorating, qualitative and quantitative changes are taking place in it from the point of view of the reliability problem increase as well as from the point of view of main pipelines operation effectiveness.

Great attention is constantly paid to the problem of gas transport system reliability and failure-free service as proper functioning of many branches of industry and public service is strongly influenced by this problem. Now the situation in this area is becoming more and more acute because of deterioration of the available main pipelines which in certain areas have completely exhausted their design service life. Large material resources are required for the new lines construction. Besides as it is proved by analysis in most cases after $30-40$ years of operation the underground gas pipeline still maintain their working ability and have sufficient reliability reserve. It is reasonable to extend their working service but it is possible only after comprehensive diagnostics of technical condition and evaluation of pipeline resources based on the calculation of residual strength and life service. Therefore the traditional methods of the calculation of pipeline strength are to be extended and added in order to consider the time as the factor resulting in pipeline bearing resistance reduce. This factor occurs mainly in fatigue, corrosion, material deterioration processes under operation conditions.

Application of the new methods of corrosion-fatigue fracture mechanics makes it possible to predict kinetics of these processes and hence to evaluate the structures residual life. Thus the problem of further development and improvement of the methods of the gas pipelines technical conditions diagnostics during operation and creation of new repair technologies including the development and improvement of the methods of repair under pressure is of primary importance.

Analysis of the researches and publications dealing with the problem of the main gas pipelines diagnostics. Long experience of pipeline systems operation indicates that existing standards of the pipeline system design and operation do not completely provide real evaluation of engineering system component stress and deformation when pipe material service is beyond the limits of elasticity under service loadings, relating in particular to those areas under extreme conditions when overloadings occur resulting in the formation of plasticdeformed areas. The list of reasons of pre-emergency operation and factors resulting in the above mentioned are described in papers [2 - 14]. As practice shows external loadings caused by the above mentioned ones acting together with internal pressure induce in the pipe walls such levels of loadings that exceed the proportion limits for main types of materials the main pipeline systems are made of. 
Statement of the task. Let us state the task to carry out diagnostics of the peculiarities of realization approach to the formation of sound estimates of residual MGP resource within the limits of basic calculation criteria depicting the main mechanisms of material bearing resistance exhaustion of the main gas pipelines.

BPresentation of the basic material. In the process of diagnostics control implementation the experienced workers who used to evaluate the equipment condition by themselves often face the difficulties while working with modern diagnostic devices. Moreover it is necessary to state the task in such a way that the diagnostic control system should be predicted while developing output requirements for any type of equipment. All requirements providing assembly and observation according to diagnostics parameters should be taking into account at the development.

One of the possible versions for buried MSP diagnostics is schematically shown in Fig. 1.

Diagnostics of the open gas pipeline includes the following operations:

- determination of the real plan-high-altitude position of MGP and comparison with the designing documents;

- visual inspection of the tube body and determination of damaged places;

- carrying out of ultrasonic failure detection and thickness measurement;

- the following is done in the same sequence as during the buried gas pipeline diagnostics (Fig. 1).

Let us describe the order of MGP diagnostics in details.

Before you start your main inspections and measurements for MGP technical state diagnostics you should carry out the desktop documents preparation, work out the plan and execute necessary preparation procedures on the route.

Pig inspection is carried out by such foreign firms as „Rosen Engineering“, „British Gas" and others. Pig inspection determines metal wastes on internal and external sides of the pipe walls, geometrical pipe and weld defects.

Pig inspection is carried out in the following way:

- working ability of pig launchers pistons receivers are checked;

- MGP interior is clened by cleaning pistons, the quality of cleaning is controlled;

- the inner pipeline geometry is investigated by profile piston;

- MGP is inspected by intellectual piston in order to determine defects;

- a report about the inspection results is drawn and obtained paremeters are stored in data base. 


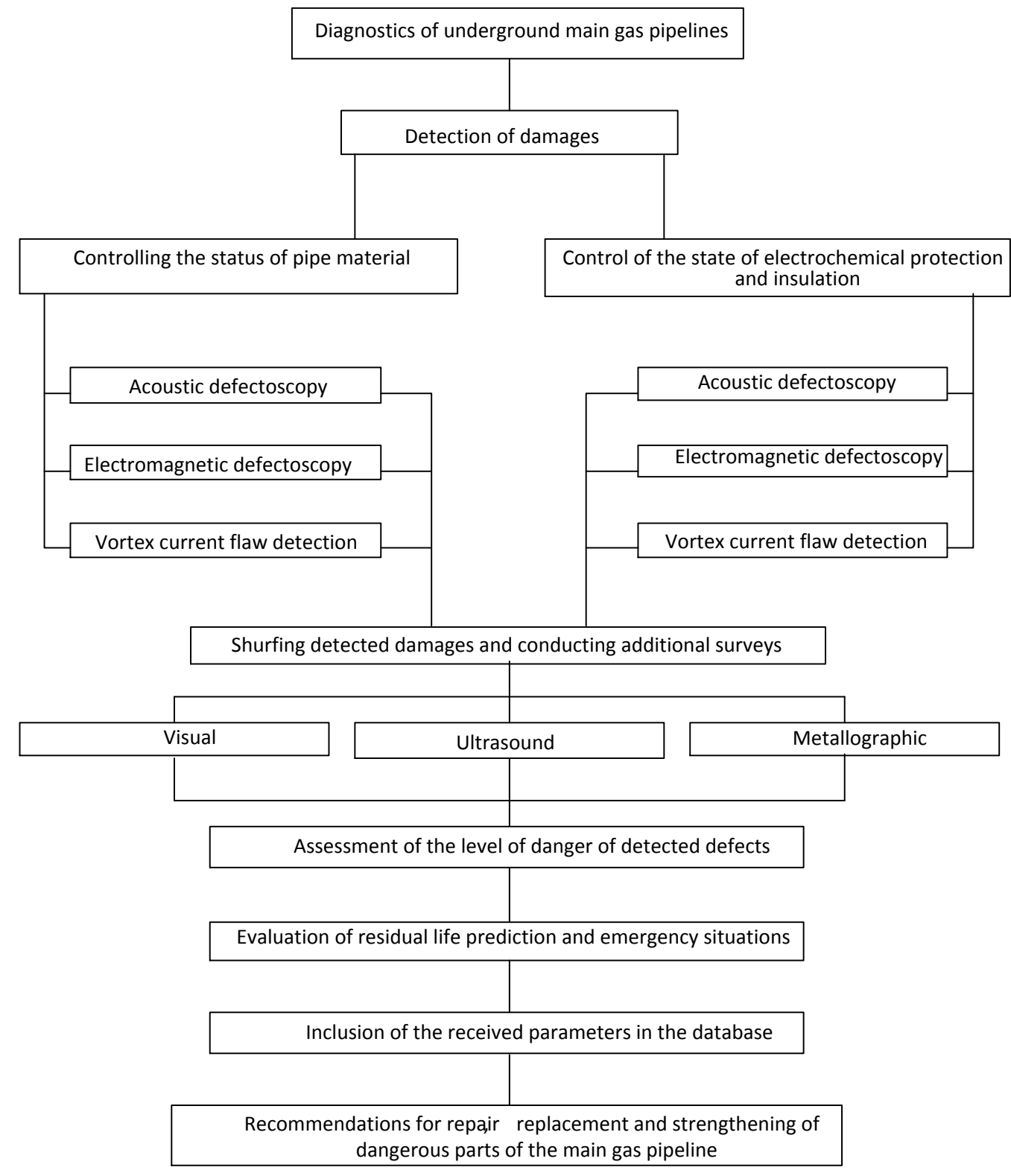

Figure 1. The scheme of carrying out of the diagnostic of buried MGP

Then the control of electrochemical protection (ECP) and isolation is carried out. There are receipt, basic and technological types of control of MGP corrosion resistance state.

The receipt inspection includes checking of availability and technical state of anticorrosive protection and their conformity to design and regulatory documents. It is carried out by means of ECP application in operation, after repairing, during changes in the anti-corrosion protection system or service.

The basic control includes determination of environment corrosion properties on the route; the state of isolation coatings; the state of ECP means; pipeline safety along length and in time; pipeline corrosion state. Technological control is carried out regularly during the year along the whole gas pipeline system and provides: sections;

- determination of the distribution of cathode protection currents in the pipelines

- determination of metal-environment potential in the pipeline inspection stations and in the places with corrosion threatening conditions.

The main parameters for protective insulation coatings control during diagnostics of 
the technical state of underground MGP under operation are:

- insulation integrity (absence of penetrating damages);

- insulation adhesion to steel;

- transfer resistance.

To control the state of protective insulation coatings of the buried MGP:

- integral estimation of transfer resistance ,pipe-ground“ in the area of cathode protection action, carried out by cathode polarization method;

- differential estimation of protective coatings quality factor on various pipeline areas and distribution of transfer resistance along the route carried out by method of noncontact current measurements, for example, by BIT-2KVP device. This device is equipped with electronic memory and mathematical support in order to automize the measurement results processing and to avoid subjective factor of the operator are used.

The damages of insulation coatings integrity of the buried pipeline (availability of penetrating insulation damages) are controlled according the current density (for example, by BIT-2KVP device) or according to electric field anomalies. The electric field anomalies are detected by contact method of trailing electrode and by differential method (insulation damage sensor with direct or quadrature electrodes location); local contrast insulation damages are detected in this case.

Inspection of the technical pipeline state in the rathole is carried out visually and instrumentally. Here:

- insulation state; adhesion, integrity (damage availability, microcracks, moisture under the coating), transfer resistance by ,wet" contact;

- availability and type of corrosion;

- place, dimensions, depth, relief of the pipe metal corrosion damages; type);

- pipe wall thickness in the place of damages (ultrasonic thickness gage of UT-93p

- soil type, salt content, humidity, availability of the ground waters) are determined.

Pipe metal inspection is additionally carried out by ultrasonic or electromagnetic methods of nondestructive control (for example by ultrasonic failure detector UD 2-12). If it is necessary the samples of insulating coatings are delivered to the laboratory for analysis and testing.

The next stage is the estimation of hazard rate of the defects geometrical dimensions defined in the pipe body.

Defects which occur in the pipe body are stresses concentrators and their availability decrease the pipe strength and when they reach their critical geometrical dimensions the gas pipeline failure occurs. That is why it is necessary to develop the methods of estimation of the geometrical dimensions of different kinds of defects on pipeline strength and residual life. The hazard rate of defects availability depends on various factors such as: defect geometry and location, dimensions and shape in the plan, availability of sharp angles producing high stresses concentration; defects orientation relatively to the pipe axis; the distance between the defect location and welding joint; branch pipes; stress state around the defect; intensity of corrosion rate; physical-mathematical properties of the material.

From the point of view of stresses concentration the defects are divided into two large groups: classical (smooth with finite size in the top, particularly corrosion pits, buckles, moving from the welding to the base metal, etc.) and fractured-type (sharp-pointed with zero radius at the top, for example cracks, scratches, undercuts in welding joints).

Depending on the shape and geometrical dimensions the defects classification and determination of their arrangement is carried out, i.e. matching models providing calculations of intensity and stress concentration coefficients are created. On this basis the calculation 
formulas, tables and diagrams for the estimation of defects geometrical dimension danger depending on the rate of nominal stresses under static loadings and standard mechanical characteristics of the pipe metal and welding joints as well as crack-resistance characteristics are obtained.

The MGP residual life with corrosion-mechanical damages predicts:

a) Estimation of residual life according to the kinetic increase of pipe extensive corrosion damages.

On the basis of the analysis of geological route peculiarities, inspection results and flaw detection control of the pipeline, the areas with the largest hazards of the pipe corrosion are determined. The corrosion rate in the pipe material are defined by:

- direct method on the basis of long-term sample tests (directly cut from the pipes) in the soil environment of the given properties and parameters (humidity, temperature, etc.);

- on the basis of correlative dependence between the growth rate of corrosion pits in unloaded material and specific electrical resistance of the soil;

- pipeline residual life relatively to the time of wall thickness decrease caused by corrosion from the given to minimum acceptable value.

b) estimation of the residual life according to the criteria of corrosion low-cycle fatigue.

Due to the nominal stress magnitudes in the defect area, the stress concentration coefficient and complete material deforming $(\sigma \sim \varepsilon)$ diagram are considered to be the top of local plastoelastic deformations $\varepsilon_{p}$ near the defect top. Using the results of the smooth samples testing under high amplitude cyclic loading and corrosion environment influence, the basic diagrams of the material low-cyclic fatigue (dependence of plastic deformation vale on the cycle amount to fracture $N_{f} 0$ are defined. Using the diagrams of the low-cycle fatigue and obtained value the period of the material fatigue fracture around the given pipe defect under operation conditions $N_{f}$ is determined. The value $N^{*}=N_{f}$ is considered to be the pipeline residual life expressed in loading cycles.

On the basis of real cyclic operation of the given pipeline area according to the diagram of operating pressure daily change on the compressor station inlet and outlet, the time durind which the given amount $N^{*}$ of loading cycles is determined. The amount $N^{*}$ defines the pipeline residual life in the real time scale.

c) estimation of residual life according to the criteria of fatigue cracks corrosion growth.

The calculation of the pipelines according to the criteria of corrosion-fatigue cracks growth are carried out in order to get information about:

- estimation of the pipe wear resistance store with detected during flaw detecting control defect-type cracks; the possibility of the determination of these defects hazard rate and emergency of repair works, analysis of the effectiveness of the pipeline repair methods (wrapping, welding on reinforcing plates, etc.);

- estimation of the period of the defect growth detected during control (which dimensions are less than sensibility limit of applied flaw detecting devices) for the analysis of pipeline residual possibilities and development of preventive measures concerning timely determination and removal of hazardous damages (particularly determination of inspection and retesting frequency, etc.).

According to methodological guidelines RD 50-345-82 the diagrams of material cyclic crack resistance in the given environment - dependences of the crack growth rate $V=\frac{d l}{d N}$ on the stress intensity range $\Delta K_{1}$ are determined experimentally.

Additionally the hazard level of the material corrosion cracking is investigated and if 
it is necessary the influence of the extended static loading on the crack growth rate is examined experimentally.

The calculation of the crack kinetic growth in the furnace influenced by operation loadings is carried out and its dimension changes depending on the amount of loading cycles $N$ is defined. The amount of loading cycles $N \sim N^{*}$ during which the defect dimensions reach the critical values is found. The value $N^{*}$ is supposed to be the pipeline residual life (in loading cycles).

Let us state the methodological principles foe the development of scientifically proven methods for the definition of the predictive assessment of the pipeline residual life under extended service. Peculiarities of such approach are that basic calculations are carried out within the theories depicting the main mechanisms of exhaustion of the load bearing capacity of the MGP pipe material.

Estimation of the residual life according to the static strength criterion. According to the existing standards [18] the main calculation factor of the pipeline strength support is the condition of edge state static strength: stresses in the pipe wall $\sigma$ should not exceed the calculated material strength of the pipe $R$

$$
\sigma<R
$$

For gas pipelines the value $\sigma$ is supposed to be equal to the circular stresses from the operating gas pressure $p \sigma=p D / 2 s$, where $D$ is the inside pipe diameter, $s$ is the wall thickness, and the value $R$ is defined by reference to the material strength limit value and safety factor selected depending on the gas pipeline category and operation conditions. Factor (1) in the basic one for project calculations and especially for pipe material and dimensions choice. Its application for pipelines operating for along time requires corrections taking into account calculated time changing parameters compared with their initial values. These changes are connected first of all with the following two factors.

First as the result of the material degradation the decrease of its strength properties is possible which means the relevant value $R$ decrease. Degradation level can be defined by testing standard samples from the pipe material cut from the gas pipeline or approximately estimate using correlative dependences between material mechanical characteristics and hardness or other physical parameters defined by nondestructive control devices directly under the route conditions [19].

Secondly corrosion and material wearing processes causing the pipe wall thickness reduction can result in effective stress $\sigma$ value increase. For buried main gas pipelines the most dangerous is the outer pipe surface corrosion where insulation is damaged or cathode protection in the areas with considerable soil corrosion activity is insufficient. The intensity of such corrosion processes can be determined by standard methods - by long-term testing of samples located in grant environment with defined properties (structure, chemical composition, humidity, temperature, etc.) For immediate engineering estimation the correlative dependences connecting corrosion wear $u_{0}$ rate with specific electrical soil resistance $\rho$ are the most widely used [20]. Experimental data prove if the magnitude $\rho$ is over $100 \mathrm{Om} / \mathrm{m}$, the influence of the soil corrosion is rather low and can be neglected; if $\rho=30-100 \mathrm{Om} / \mathrm{m}$, the soil corrosion activity is high ( $u_{0}=0,02-0,14 \mathrm{~mm} /$ year), and if $\rho<30 \mathrm{Om} / \mathrm{m}$, it is very high. Besides it is well known that corrosion processes are accelerated by mechanical stresses effect; these effect can be represented, for example, by linear dependence [21]

$$
u=u_{0}\left(1+k \sigma_{0}\right)
$$


$u, u_{0}$, being corrosion rate in loaded and unloaded material correspondently; $\sigma_{0}$ being hydrostatic component of the stress tensor; $k$ being constant coefficient (specifically for pipe steels it is $k=0,041 / \mathrm{MPa}$ ). Above given dependences are essential for calculation of corrosion rate estimation in the pipe wall taking into account the rout passage and the acting load level.

All in all taking into account both factors we can predict the dynamics of initial pipeline strength factor decrease and estimate the residual life as boundary acceptable time 9 in the sense of condition according to the criteria (1).

Estimation of residual life according to low-cyclic fatigue criterion. During operation the main gas pipelines undergo repeated-static loading: the value of the operation pressure on the compressor station discharge changes while both line productivity and pipelining mode are changing; the main gas pipelines are regularly deactivated for planned preventive measures implementation, trouble shooting, etc. On the average the number of such changes during warranty gas pipeline operation time (30 years) is $0,8-1,2-10^{4}$ cycles. At the same time for certain gas pipeline areas depending on their state and the loading level the number of these cycles can be larger (or run out in shorter period of time). All this is the evidence of the importance of calculation estimation of the gas pipelines working capacity from point of view of the low-cyclic fatigue. Methodological principles of such calculations are presented in papers $[22,23]$. From the basic diagrams of the material low cyclic fatigue the service life is defined by coordinates: plastic deformation $\left(\varepsilon_{p}\right)$ amplitudes - the number of loading cycles till fracture (or macrofracture). In its turn to define local field of plastoelastic deformations in the prefracture area total curves of the material cyclic deformation $(\sigma \sim \varepsilon)$ and approximations of Neuberg's type $k_{\sigma} k_{c}=\alpha^{2}$, where $\alpha$ is geometric stress concentration factor; $k_{\sigma}, k_{\varepsilon}$-are real plastoelastic stress and deformation concentration factors relatively are used.

Calculation according to such scheme provides pipeline residual life prediction with consideration of fatigue cracks origin near constructive stress concentrator (i.e. related to welding joints), defects and damages such as buckles, scratches, corrosion cavities, etc. However its implementation as to underground pipelines after long-term operation requires additional consideration of corrosion and material aging. The influence of both factors is sufficient. Particularly the evaluation of the low-cyclic fatigue diagram according to material mechanical characteristics [24] shows that after 25 years of operation the period of crack origin can be 3-4 times shorter than in output material under the same loading conditions. In the soils with high corrosion activity (for instance, swampy or clay soils with sulfate-reducing bacteria) fatigue cracking process can be speeded up almost 3 times. Besides the development and application of calculating models accounting the interaction of electrochemical corrosion processes during fatigue cracking under repeated static loading and environmental influence is an important course of calculation method improvement and results validity increase.

Estimation of residual life according to crack resistance criterion. Corrosion-fatigue crack propagation causes about one third of pipeline failures providing that the longer the operation time, the larger their amount. That is why to provide required level of material crack resistance is important for the pipeline failure-free operation and is essential resource of its life time increase. Within fatigue fracture mechanics [25] the residual life of the construction element when it has crack-like defect is determined by the formula

$$
N^{*}=\int_{l_{0}}^{l_{*}} \frac{d l}{F\left(\Delta K_{1}\right)},
$$

where $N^{*}$ is the period (loading cycles number) of crack growth from initial $\left(l_{0}\right)$ to critical $\left(l_{*}\right)$ 
size; the value $F\left(\Delta K_{1}\right)=\frac{d l}{d N}$ dependance of growth rate from stress intensity range for period $N_{j}$ determining by kinetic diagram of fatigue fracture for the given material under given loading conditions. The value $\Delta K_{1}$ for the defect of given configurationand and dimensions is calculated on the basis of the solution of relative solution of elasticity theory; for the largest typical defects such solutions are presented in reference guides [25].

While calculating gas pipelines, consideration of the following factors sufficiently influencing the fatigue crack growth are of fundamental significance.

Plastic behavior of the material. For gas pipeline construction sufficiently toughened steels which destruction is followed by plastic deformation are used. In most cases when fatigue cracks grow the self-similarity models (conditions of small plastic areas) are broken making the use of linear fracture mechanics unacceptable. The possible way out is to carry out the calculation on the basis of generalized $\delta_{k}$-model within the deformation approach. For this the kinetic diagrams of fatigue failure are presented in the form of dependence of crack growth rate on the rate of crack opening on its apex $\Delta \delta$. The value $\Delta \delta$ for real defect can be estimated by stress intensity coefficient $K_{1}$ using approximative method of equivalent stress conditions $[25,26]$. Besides the application of $\delta_{k}$-model offers exciting possibilities for modeling of material reverse elastoplastic deformation (including the effects of fracture closure) which in its turn extends the predictive ability and increases the calculation accuracy of corrosion-fatigue crack kinetic growth under various loading conditions [27].

The influence of corrosion environment. Similar to the case of low-cyclic fatigue, corrosion environments, particularly soil, are the factors sufficiently influensing the material cyclic corrosion-fatigue growth resistance. This influence can be determined experimentally by the construction of material cyclic-fatigue fracture, testing the standard samples with crackscuts under cyclic loadings and corrosion environment influence. During this investigations the crack growth rate is controlled on the one hand and on the other hand the parameters of stressstrain state and parameters of physico-chemical situation near the crack apex [25, 28]. Directly in laboratory setting it is practically impossible to represent the whole variety of metalenvironment-loading conditions combinations implemented in gas pipeline operation. That is why the development and application of calculating models providing the prediction of corrosion-fatigue cracks growth under various conditions according to basic experiment results are of significant importance [29]. Finally while carrying out calculations it is necessary to take into account not only intensifying influence of corrosion environment on fatigue crack growth but also the possibility of corrosion cracking under stress (stress-corrosion): it is evident that the real process of gas pipeline fracture is the combination of both mechanisms.

Material aging. Material degradation in the operation process to a greater extend is evident as plastic properties decrease - material crushing. So sufficient decrease in cyclic and static crack resistance is expected. According to certain data due to the material aging the fatigue crack growth rate is increased $2-3$ times [24]. It is clear that the degradation process essentially depends on corrosion. Besides it is uniformely developd on pipe wall which should be also taken into account during crack growth analysis.

Control of the state of cathodic and insulation protection is carried out at least every five years [30]. In this regard mobile measurement laboratories are mounted on the basis of automobiles UAZ, ZIL or Gazel.

The laboratories are equipped with necessary installation to carry out complex tasks regarding anticorrosion and cathodic protection parameters control including the system of „Modata“ mobile registration, timing detector „Syntakt“, copper-scopper sulfate electrodes, 
digital millivoltmeters, pipeline finders, on-board computers, etc.

For main pipelines which operation time is more than 20 years pig inspection using intellectual products of ,Rosen Engineering GmbH“, Pipetronix i British Gas firms are applied. In order to carry out in-line inspection it is necessary to perform a great number of preliminary works such as:

- to test piston launchers and receivers;

- to clean the MGP interior by means of special cleaning pistons;

- to test inside geometry by means of geometrical pistons and only then to carry out inspection by intellectual piston.

Mathematical support makes it possible to analyse and return inspection results in the form of graphical dependences and diagrams presented in specified Figures $2-6$ [31].

Fig. 2 shows us detected pipe damages in the form of the function of their location from edge welds. It can be seen here that the amount of amomalies decreases with the increase of the distance from the edge weld.

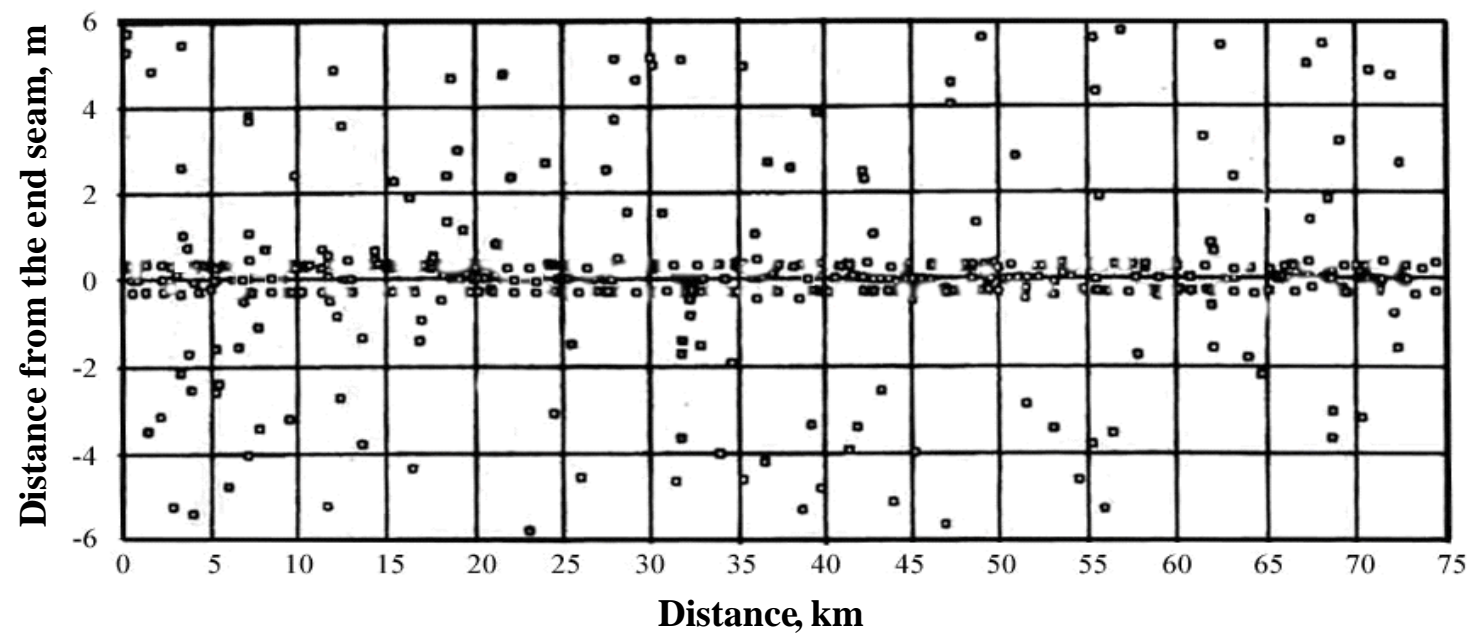

Figure 2. The function of the location of the detected damages from their location relatively to the edge welds

The diagram of the damage distribution along the pipe length is shown in Fig. 3. The amount of damages depending on the wall thickness decrease $>50 \%$ is shown in the first row; in the second one - from 31 to 50\%; and in the third - from $10-30 \%$.

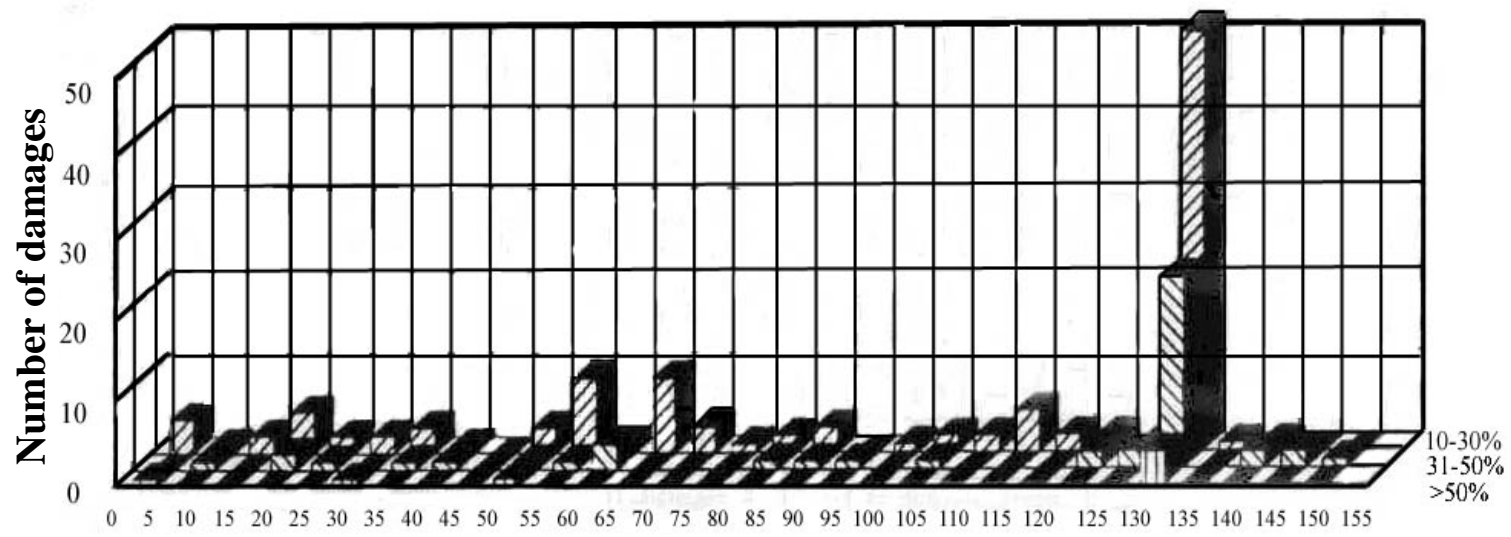

Distance, $\mathrm{km}$

Figure 3. Diagram of the damage distribution along the pipe length 
To inspect the damaged places the probing with visual inspection of pipe body and insulation, wall thickness test, flaw inspection and soil analysis are performed.

The algorithm of the open MGP inspection, for instance on water barrier and swamp area transitions is shown in Fig. 4. The results of the inspection are stored in database. Special supply for storing, reviewing and analysis of information found out during inspections is developed.

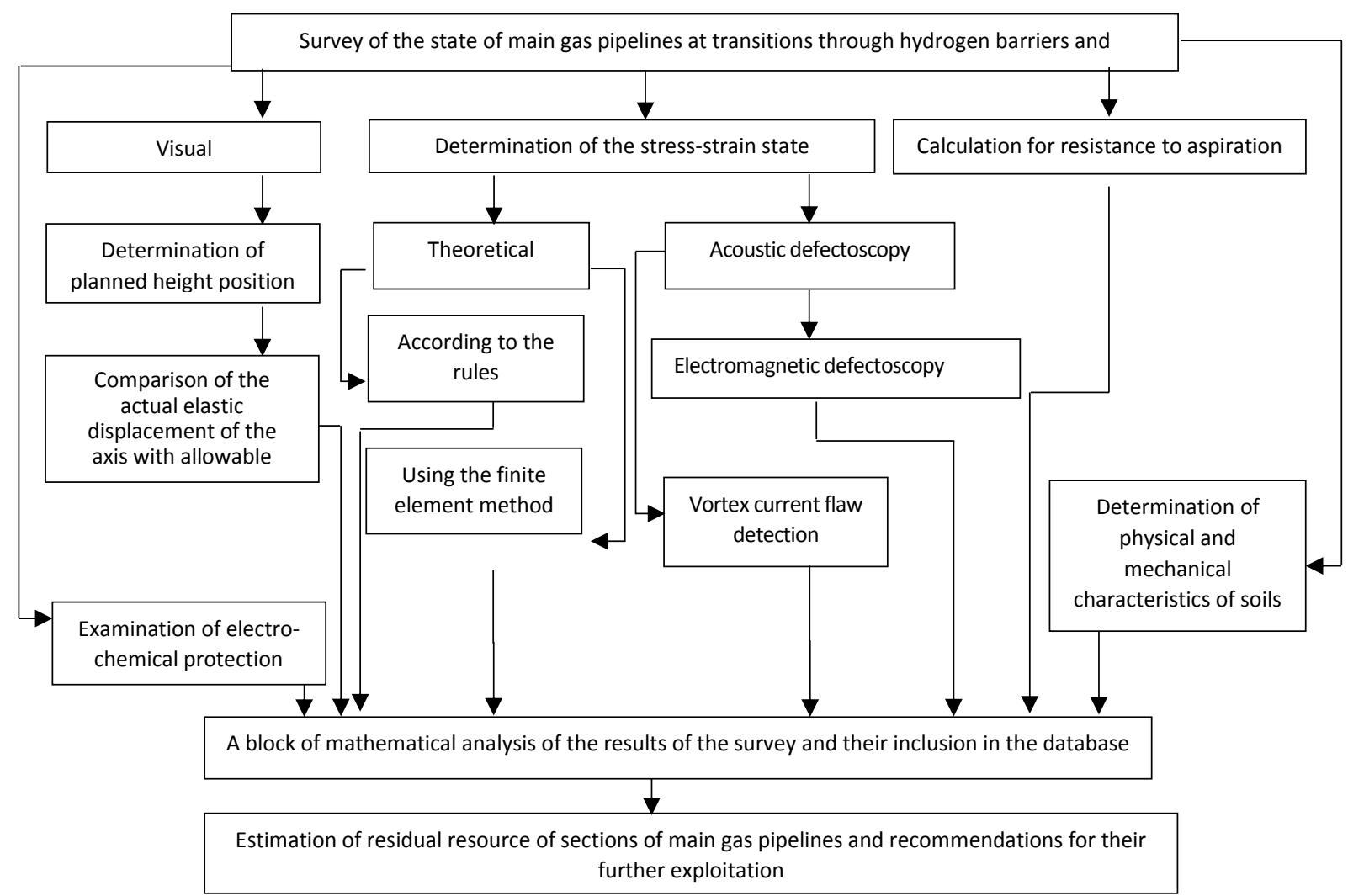

Figure 4. The algorithm for monitoring the state of gas main at transitions through water obstacles and wetlands

The degree of danger of corrosion defects of the pipeline pipe spoke can be determined approximate estimation accordind to the diagram given in paper [32] (Fig. 5). 


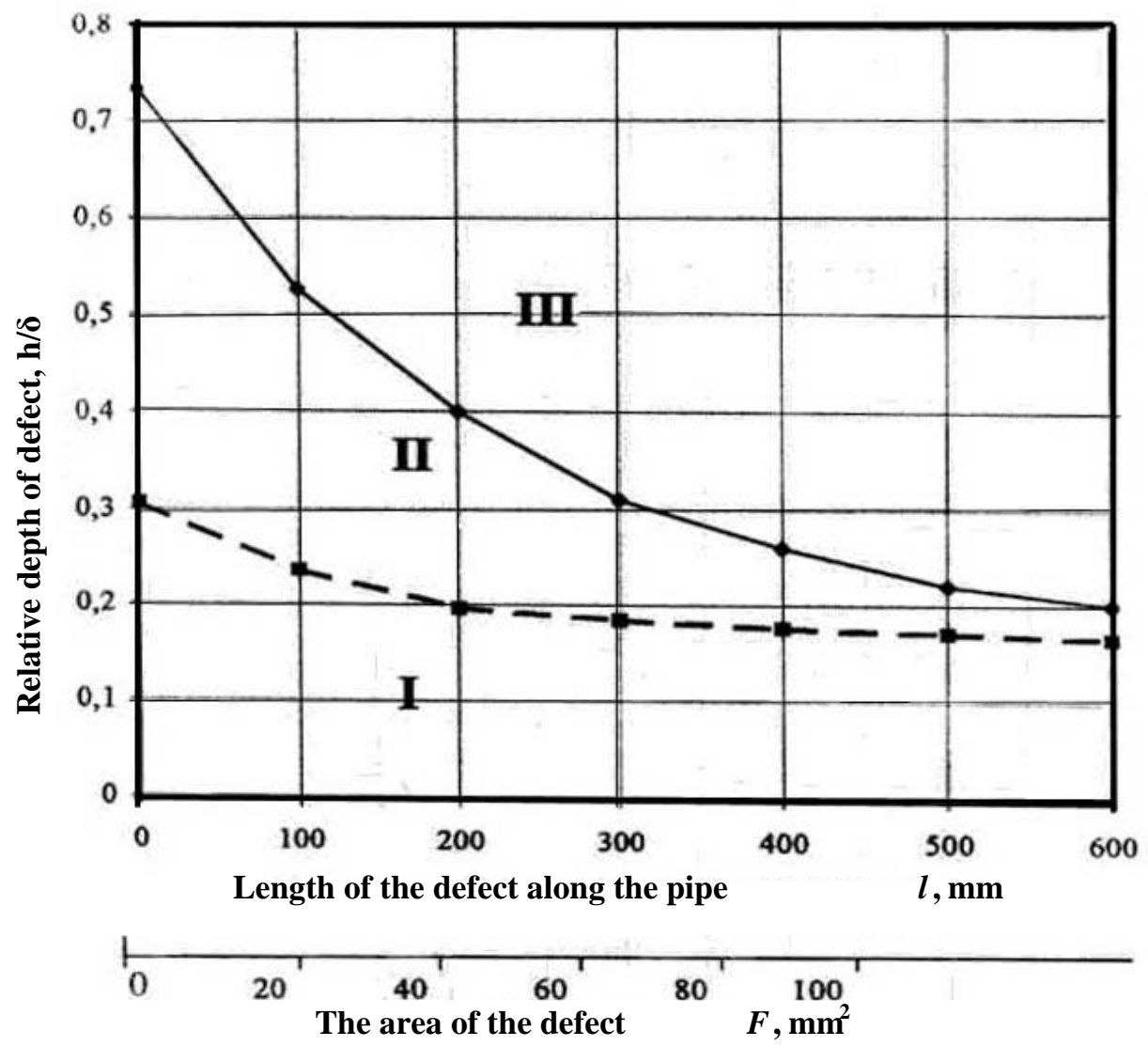

Figure 5. Diagram for determining the degree of danger of corrosion defects in the walls of the pipe of the gas pipeline: I - the zone of relative safety, requires increased control; II - zone of dangerous defects, an expert decision on the method of restorative work is needed; III - a particularly dangerous zone, it is necessary to immediately reduce the internal pressure in the gas pipeline and replace the defective section

The estimation of possible application of the pipe with detecteddefect can be carried out according to the estimation repair factor ERF as well. This repair factor ERF is calculated by standard formulas ASME B31.4 or ASME B31.8 (Fig. 6).

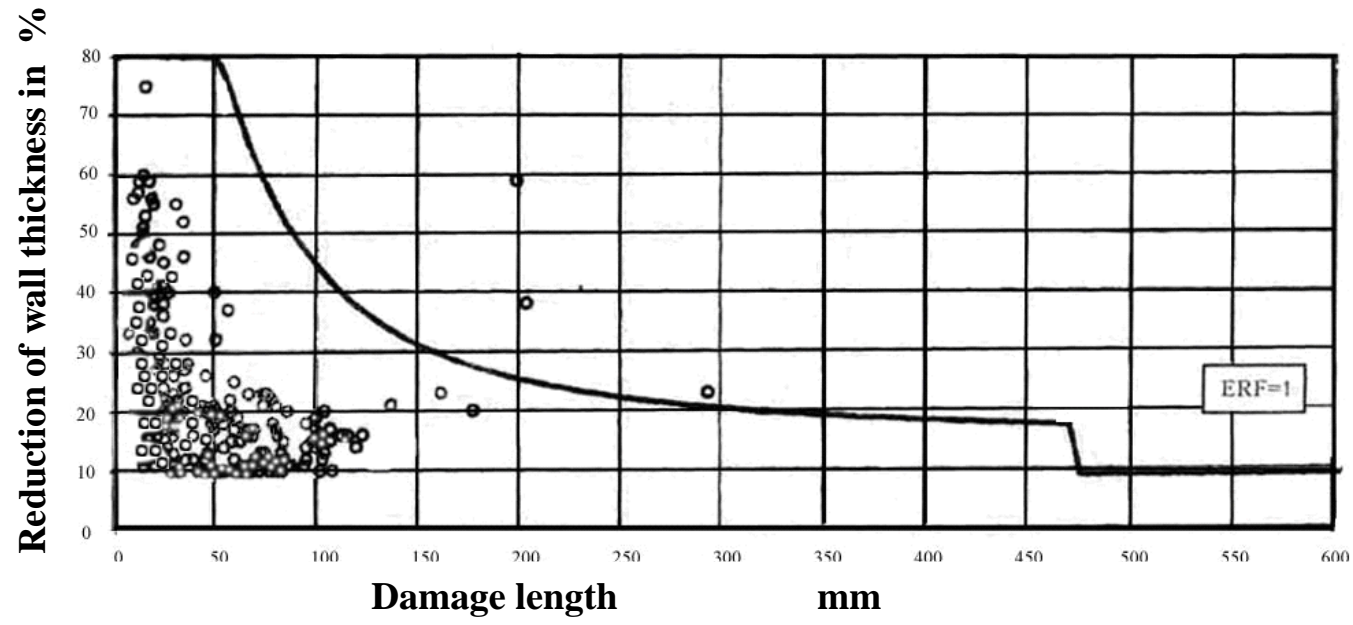

Figure 6. Diagram of the estimates coefficient 
For more detailed evaluation of detected defect danger the other methods can also be used. Among them are: the finite element method; residual life estimation according to static strength criterion; residual life estimation according to kinetics of the pipe extensive damage growth; taking into account corrosion rate in pipe material according to failure risk coefficient; residual life estimation according to the criterion of corrosion-fatigue crack growth which should be adapted to the gas industry conditions.

Conclusions. Using the information obtained during the previous stages, the entry of the received parameters into the database is carried out. The large amount of static and dynamic gas main diagnostic parameters in time requires the creation of special means of input, saving, obtaining reference database elements. On the one hand, considerable amounts of parameters, and on the other - the need for their structuring according to the administrative and functional features of the enterprise conditions determine the optimality of the database management system (DBMS). Management of JSC „Ukrgasprom“ stopped to implement the Hungarian system of DBMS focused on ORACLE. The means of data transmission between the client and the server in the system are the network and switching software (Novel, Windows NT), available to the client and server.

On the basis of the data obtained during the diagnosis, and the results of calculations, recommendations for the repair, replacement and strengthening of hazardous areas of the main gas pipelines are developed. Regular diagnostics of the main gas pipelines in the abovementioned volume gives us an opportunity of effective determination of the technical state of main gas pipelines and allows us to establish the expediency of further exploitation and recommendations for the elimination of detected defects.

Criteria for static strength of low cycle fatigue and cyclic crack resistance reflect the main characteristic of the practice of the mechanisms of destruction of main gas pipelines. Considering the aging of the material and the effect of corrosion significantly increases the predictive ability of these criteria. The calculations carried out on their basis combined with the data of field inspections and, in particular, defectoscopy, can provide a fairly objective assessment of the actual technical condition and resource capabilities of the pipeline. These results can be successfully used to justify the permissible period of exploitation of the gas pipeline (including outside the boundary of the initial, project resource), prediction of optimal terms and necessary nomenclature of repair works, development of a system of preventive measures for the timely detection and elimination of hazardous damage, as well as solving other practical problems connected with ensuring the efficient and effective operation of gas transmission lines.

\section{References}

1. Rozghoniuk V.V. Hazotransportna systema Ukrhazpromu. Hazova promyslovist Ukrainy 1974 - 1994, pp. 21 - 22. [In Ukrainian].

2. Agapkin V.M., Borisov S.N. Spravochnoe posobie po raschetam truboprovodov. Moscow, Nedra, 1987. 191p. [In Russian].

3. Ajsbinder A.B. Raschet magistral'nyx i promyshlennyx truboprovodov na prochnost' i ustojchivost'. Moscow, Nedra, 1991. 287 p. [In Russian].

4. Aksel'rod E.A., Il'in V.P. Raschet truboprovodov. Leningrad, Mashinostroenie, 1972. 240 p. [In Russian].

5. Anuchkin M.P., Gorickij V.N. Truby dlya magistral'nyx truboprovodov i usloviya ix nerazrusheniya. Moscow, Nedra, 1986. 230 p. [In Russian].

6. Bazhenov V.A. Raschet cilindricheskix obolochek truboprovodov: Uchebnoe posobie. Kiev, KISI, 1977. 108 p. [In Russian].

7. Borisov V.V. Remont magistral'nyx truboprovodov. Moscow, Gostoitexizdat, 1958. 110 p. [In Russian].

8. Borodavkin P.P., Berezin V.L. Sooruzhenie magistral'nyx truboprovodov: Uchebnik dlya vuzov po special'nosti Sooruzhenie gazonefteprovodov. Moscow, Nedra, 1987. 471 p. [In Russian].

9. Borodavkin, P.P., Sinyukov A.M. Prochnost' magistral'nyx truboprovodov. Moscow, Nedra, 1984. 245 p. [In Russian]. 
10. Zavojchinskij B.I. Dolgovechnost' magistral'nyx i texnologicheskix truboprovodov. Moscow, Nedra, 1992. 271 p. [In Russian].

11. Kamershtejn A.G. Usloviya raboty stal'nyx truboprovodov i rezervy ix nesushhej sposobnosti. Moscow, Strojizdat, 1966. 242 p. [In Russian].

12. Morozov V.N. Magistral'nye truboprovody v slozhnyx inzhenerno-geologicheskix usloviyax. Leningrad, Nedra, 1987. 123 p. [In Russian].

13. Perun I.V. Magistral'nye truboprovody v gornyx usloviyax. Moscow, Nedra, 1987. 175 p. [In Russian].

14. Ruchimskij M.N. Raschet truboprovodov na prochnost'. Moscow, Nedra, 1969. 440 p. [In Russian].

15. Xismatullin E.R. i dr. Sosudy i truboprovody vysokogo davleniya. Moscow, Mashinostroenie, 1990. 382 p. [In Russian].

16. Xarionovskij V.V. Nadezhnost' i resurs konstrukcij gazoprovodov. Moscow, Nedra, 2000. 467 p. [In Russian].

17. Turkin V.S. O nesushhej sposobnosti truboprovodov iz stal'nyx trub. Stroitel'naya mexanika i raschet sooruzhenij, 1960, no. 1, pp. 32 - 38. [In Russian].

18. SNiP-2.05.06-85. Stroitel'nye normy i pravila: Normy proektirovaniya magistral'nyx truboprovodov. Moscow, Strojizdat, 1985. 62 p. [In Russian].

19. Pashkov Yu.I., Anisimov Yu.I., Lapchakov G.A. i dr. Prognozirovanie ostatochnogo resursa prochnosti magistral'nyx gazonefteprovodov s uchyotom prodolzhitel'nosti e'kspluatacii. Stroitel'stvo truboprovodov, 1996, no. 2, pp. 2 - 5. [In Russian].

20. Strizhevskij I.V. Podzemnaya korroziya i metody zashhity. Moscow, Metallurgiya, 1986. 110 p.

21. Gutman E.M., Zajnullin R.S., Shatalov A.T. i dr. Prochnost' gazopromyshlennyx trub v usloviyax korrozionnogo iznosa. Moscow, Nedra, 1984. 76 p. [In Russian].

22. Normy raschyota na prochnost' e'lementov reaktorov, parogeneratorov, sosudov i truboprovodov atomnyx e'lektrostancij, opytnyx i issledovatel'skix yadernyx reaktorov i ustanovok. Moscow, Metallurgiya, 1973. 408 p. [In Russian].

23. Gusenkov A.P., Moskvitin G.M., Xoroshilov V.N. Malociklovaya prochnost' obolochechnyx konstrukcij. Moscow, Nauka, 1989. 254 p. [In Russian].

24. Gumerov A.G., Gumerov K.M., Roslyakov A.V. Razrabotka metodov povysheniya resursa dlitel'no e'kspluatiruyushhixsya nefteprovodov. Moscow, VNIIOE'NG, 1991. Obzorn. inform. Ser. „Transport i xranenie nefti“. 80 p. [In Russian].

25. Mexanika razrusheniya i prochnost' materialov: Sprav. posobie: Pod obshhej red. Panasyuka V.V. Kiev. Nauk. dumka, 1988. [In Russian].

26. Andrejkiv A.E., Darchuk A.I. Ustalostnoe razrushenie i dolgovechnost' konstrukcij. Kiev, Nauk. dumka, 1992. 184 p. [In Russian].

27. Panasyuk V.V. Fracture mechanics of materials and methods of assessment of structures service life-time: success and prospects, V.V. Panasyuk, O.Ye. Andreykiv. Advances in Fracture Research: Proc. of the 9 International Conference of Fracture (ICF-9). Sydney, Australia, 1 - 5 April 1997. V. 1, pp. 105 - 116.

28. Romaniv O.H., Nikiforchin G.N. Mexanika korrozionnogo razrusheniya konstrukcionnyx splavov. Moscow, Metallurgiya, 1986. 294 p. [In Russian].

29. Influence of hydrogen-containing environments on fatigue crack extension resistance of metals, Panasyuk V.V., Andreykiv O.Ye., DarchukO.I., Kuznyak N.V. In: Handbook of Fatique Crack Propagation in Metallic Structures, Ed. Carpinteri A. Amsterdam e.a: Elsevier Science B.V., 1994, pp. 1205 - 1242.

30. Polozhennia pro tekhnichnyi nahliad za yakistiu sporudzhennia, rekonstruktsii, kapitalnoho remontu, vykonannia puskonalahodzhuvalnykh robit i bezpechnoiu ekspluatatsiieiu obiektiv mahistralnykh hazoprovodiv. Dnipropetrovsk, 1999. 30 p. [In Ukrainian].

31. Kychma A.O., Koval R.I., Zubyk Y.L. Diahnostyka hazoprovodiv $\mathrm{z}$ dovhotryvalym terminom ekspluatatsii. Zb. nauk. pr. Diahnostyka, dovhovichnist ta rekonstruktsiia mostiv ta budivelnykh konstruktsii. Lviv: Kameniar, 2000. Vol .2, pp. 50 - 58. [In Ukrainian].

32. Metodyka otsinky tekhnichnoho stanu metalu diiuchoho hazoprovodu z tryvalym strokom ekspluatatsii (bilshe 10 rokiv) ta zalyshkovoho resursu yoho bezpechnoi roboty. Kharkiv, 1997. 55 p. [In Ukrainian].

\section{Список використаної літератури}

1. Розгонюк, В.В. Газотранспортна система Укргазпрому. Газова промисловість України 1974 - 1994 [Текст] / В.В. Розгонюк. - С. $21-22$.

2. Агапкин, В.М. Справочное пособие по расчетам трубопроводов [Текст] / В.М. Агапкин, С.Н. Борисов. - М.: Недра, 1987. - 191 с.

3. Айсбиндер, А.Б. Расчет магистральных и промышленных трубопроводов на прочность и устойчивость [Текст] / А.Б. Айсбиндер. - М.: Недра, 1991. - 287 с. 
Diagnostics of the main gas pipelines and assessment of their residual life under the conditions of long-term operation

4. Аксельрод, Е.А. Расчет трубопроводов [Текст] / Е.А. Аксельрод, В.П. Ильин. $\quad$ - Л.: Машиностроение, 1972. - 240 с.

5. Анучкин, М.П. Трубы для магистральных трубопроводов и условия их неразрушения [Текст] / М.П. Анучкин, В.Н. Горицкий. - М.: Недра, 1986. - 230 с.

6. Баженов, В.А. Расчет цилиндрических оболочек трубопроводов: учебное пособие [Текст] / В.А. Баженов. - Киев: КИСИ, 1977. - 108 с.

7. Борисов, В.В. Ремонт магистральных трубопроводов / В.В. Борисов. - М.: Гостоптехиздат, 1958. $110 \mathrm{c}$.

8. Бородавкин, П.П. Сооружение магистральных трубопроводов: учебник для вузов по специальности Сооружение газонефтепроводов [Текст] / П.П. Бородавкин, В.Л. Березин. - М.: Недра, 1987. $471 \mathrm{c}$.

9. Бородавкин, П.П. Прочность магистральных трубопроводов [Текст] / П.П. Бородавкин, А.М. Синюков. - М.: Недра, 1984. - 245 с.

10. Завойчинский, Б.И. Долговечность магистральных и технологических трубопроводов [Текст] / Б.И. Завойчинский. - М.: Недра, 1992. - 271 с.

11. Камерштейн, А.Г. Условия работы стальных трубопроводов и резервы их несущей способности [Текст] / А.Г. Камерштейн. - М.: Стройиздат, 1966. - 242 с.

12. Морозов, В.Н. Магистральные трубопроводы в сложных инженерно-геологических условиях [Текст] / В.Н. Морозов. - Л.: Недра, 1987. - 123 с.

13. Перун, И.В. Магистральные трубопроводы в горных условиях [Текст] / И.В. Перун. - М.: Недра, 1987. $-175 \mathrm{c}$.

14. Ручимский, М.Н. Расчет трубопроводов на прочность [Текст] / М.Н. Ручимский. - М.: Недра, 1969. $-440 \mathrm{c}$.

15. Сосуды и трубопроводы высокого давления [Текст] / Е.Р. Хисматуллин и др. - М.: Машиностроение, 1990. - 382 с.

16. Харионовский, В.В. Надежность и ресурс конструкций газопроводов [Текст] / В.В. Харионовский. - М.: Недра, 2000. - 467 с.

17. Туркин, В.С. О несущей способности трубопроводов из стальных труб [Текст] / В.С. Туркин // Строительная механика и расчет сооружений. - 1960. - № 1. - С. 32 - 38.

18. СНиП-2.05.06-85. Строительные нормы и правила: Нормы проектирования магистральных трубопроводов. - М.: Стройиздат, 1985. - 62 с.

19. Прогнозирование остаточного ресурса прочности магистральных газонефтепроводов с учётом продолжительности эксплуатации [Текст] / Ю.И. Пашков, Ю.И. Анисимов, Г.А. Лапчаков и др.// Строительство трубопроводов. - 1996. - № 2. - С. 2 - 5.

20. Стрижевский, И.В. Подземная коррозия и методы защиты [Текст] / И.В. Стрижевский. - М.: Металлургия, 1986. - 110 с.

21. Прочность газопромышленных труб в условиях коррозионного износа [Текст] / Э.М. Гутман, Р.С. Зайнуллин, А.Т. Шаталов и др. - М.: Недра, 1984. - 76 с.

22. Нормы расчёта на прочность элементов реакторов, парогенераторов, сосудов и трубопроводов атомных электростанций, опытных и исследовательских ядерных реакторов и установок. - М.: Металлургия, 1973. - 408 с.

23. Малоцикловая прочность оболочечных конструкций [Текст] / А.П. Гусенков, Г.М. Москвитин, В.Н. Хорошилов. - М.: Наука, 1989. - 254 с.

24. Гумеров, А.Г. Разработка методов повышения ресурса длительно эксплуатирующихся нефтепроводов [Текст] / А.Г. Гумеров, К.М. Гумеров, А.В. Росляков. - М: ВНИИОЭНГ, 1991. Обзорн. информ. - Сер. «Транспорт и хранение нефти». $-80 \mathrm{c.}$

25. Механика разрушения и прочность материалов: справ. пособие: в 4 т.; под общей ред. Панасюка В.В. - К.: Наук. думка, 1988.

26. Андрейкив, А.Е. Усталостное разрушение и долговечность конструкций [Текст] / А.Е. Андрейкив, А.И. Дарчук. - К.: Наук. думка, 1992. - 184 с.

27. Panasyuk V.V. Fracture mechanics of materials and methods of assessment of structures service life-time: success and prospects, V.V. Panasyuk, O.Ye. Andreykiv. Advances in Fracture Research: Proc. of the 9 International Conference of Fracture (ICF-9). Sydney, Australia, 1 - 5 April 1997. V. 1, pp. 105 - 116.

28. Романив, О.Н. Механика коррозионного разрушения конструкционных сплавов [Текст] / О.Н. Романив, Г.Н. Никифорчин. - М.: Металлургия, 1986. - 294 с.

29. Influence of hydrogen-containing environments on fatigue crack extension resistance of metals, Panasyuk V.V., Andreykiv O.Ye., DarchukO.I., Kuznyak N.V. In: Handbook of Fatique Crack Propagation 
in Metallic Structures, Ed. Carpinteri A. Amsterdam e.a: Elsevier Science B.V., 1994, pp. 1205 - 1242.

30. Положення про технічний нагляд за якістю спорудження, реконструкції, капітального ремонту, виконання пусконалагоджувальних робіт і безпечною експлуатацією об'єктів магістральних газопроводів. - Дніпропетровськ, 1999. - 30 с.

31. Кичма, А.О. Діагностика газопроводів з довготривалим терміном експлуатації [Текст] / А.О. Кичма, P.І. Коваль, Й.Л. Зубик: Зб. наук. пр. Діагностика, довговічність та реконструкція мостів та будівельних конструкцій. Львів: Каменяр, 2000. - Вип. 2. - С. 50 - 58.

32. Методика оцінки технічного стану металу діючого газопроводу з тривалим строком експлуатації (понад 10 років) та залишкового ресурсу його безпечної роботи. - Харків, 1997. - 55 с.

\title{
УДК 622.692.4
}

\section{СТАН ДІАГНОСТИКИ МАГІСТРАЛЬНИХ ГАЗОПРОВОДІВ ТА ОЦІНЮВАННЯ ЇХ ЗАЛИШКОВОГО РЕСУРСУ В УМОВАХ ДОВГОТРИВАЛОЇ ЕКСПЛУАТАЦЇ̈}

\author{
Йосип Лучко ${ }^{1}$; Свген Іваник ${ }^{2}$ \\ ${ }^{1}$ Львівський філіал Дніпропетровського національного університету \\ залізничного транспорту імені академіка В. Лазаряна, Львів, Україна \\ ${ }^{2}$ Національна академія сухопутних військ імені гетьмана \\ Петра Сагайдачного, Львів, Украйна
}

Резюме. Проаналізовано сучасний стан діагностики магістральних газопроводів. Відзначено, що газовидобувний та газотранспортний комплекс нині відіграє важливу роль у структурі економіки Украӥни. Розглянуто його як галузь, яка повинна забезпечити виконання важливих проектів зменшення енергетичної кризи в країні. Розглянуто деякі аспекти реалізації діагностики відкритих та захованих ділянок магістральних газопроводів. Викладено методологічні засади побудови науково-обгрунтованої методики формулювання прогнозної оцінки залишкового ресурсу газопроводів в умовах довготривалої експлуатації. Особливості реалізації такого підходу полягають у тому, щуо базові розрахунки критеріїв виконано в рамках теорій, щуо відображають основні механізми вичерпання несучої здатності матеріалу труб газопроводів, зокрема за критерієм статичної міцності, з урахуванням процесів корозії та зношування матеріалу, оцінювання залишкового ресурсу за критерієм малоциклової втоми. Це дозволяє прогнозувати залишковий ресурс трубопроводу з урахуванням процесів зародження втомних тріщин біля конструктивних концентраторів напружень, оцінювати залишковий ресурс за критерієм тріщиностійкості. На основі даних, отриманих під час проведення діагностики, і результатів розрахунків розроблено рекомендації з ремонту, заміни та змічнення небезпечних ділянок магістральних газопроводів. Їх регулярна діагностика дає можливість ефективно визначати технічний стан і дозволяє встановити доичільність подальшої експлуатаиії і рекомендації з усунення виявлених дефектів.

Ключові слова: діагностика магістральних трубопроводів, газовий комплекс, алгоритм, сучасні методи корозійної втомної міцності матеріалів, малоциклова втома, виявлення дефектів.

Отримано 03.10.2017 